\title{
Consumer preferences toward organic food and the moderating role of knowledge: a case of Pakistan and Malaysia
}

\section{Umair Kashif ${ }^{* *}$ Chen Hong ${ }^{1 *}$ Snovia Naseem $^{1}$ (D) Waris Ali Khan' ${ }^{2}$ Muhammad Waqar Akram ${ }^{1}$}

${ }^{1}$ College of Economics and Management, Northeast Forestry University, Harbin, 150040, Heilongjiang, China. E-mail: nefuchenhong@yeah.net. ${ }^{*}$ Corresponding author.

${ }^{2}$ Faculty of Business, Economics and Accountancy, Universiti Malaysia Sabah.

ABSTRACT: The present study aimed to identify the elements of the Theory of Planned Behaviour along with health consciousness and determine the role of knowledge as a moderating variable in Pakistan and Malaysia. Three hundred and forty-one observations from Pakistan and 280 observations from Malaysia were acquired through questionnaire; while, confirmatory factor analysis and structural equation modelling was applied for the analysis. The magnitude of the results varied across both countries; however, attitude, subjective norms and health consciousness, as well as their interaction terms, were significant predictors, whereas, perceived behavioural control and its knowledge interaction terms had insignificant impacts on the purchase intentions of consumers for both countries. This research will help to further understand about consumer perception in the purchase of organic food items, which will assist retailers, advertisers and manufacturers in developing strategies for such products.

Key words: organic agriculture, consumer buying behaviour, theory of planned behaviour, confirmatory factor analysis, marketing, sustainability.

Fatores que afetam as preferências do consumidor na intenção de compra de alimentos orgânicos e o papel moderador do conhecimento no Paquistão e na Malásia

RESUMO: O presente estudo teve como objetivo identificar os elementos da teoria do comportamento planejado juntamente com a consciência em saúde, e determinar o papel do conhecimento como uma variável moderadora no Paquistão e na Malásia. 341 observações do Paquistão e 280 observações da Malásia foram adquiridas através de questionário; enquanto que análise fatorial confirmatória e modelagem de equações estruturais foram aplicadas para a análise. A magnitude dos resultados variou entre os dois países. No entanto, atitudes, normas subjetivas e consciência da saúde, bem como seus termos de interação, foram preditores significativos, enquanto que controle comportamental percebido e seus termos de interação do conhecimento tiveram impactos insignificantes nas intenções de compra dos consumidores para os dois países. Esta pesquisa ajudará a entender melhor a percepção do consumidor na compra de alimentos orgânicos, o que ajudará varejistas, anunciantes e fabricantes no desenvolvimento de estratégias para esses produtos.

Palavras-chave: agricultura orgânica, comportamento de compra do consumidor, teoria do comportamento planejado, análise fatorial confirmatória, marketing, sustentabilidade.

\section{INTRODUCTION}

Globally, regulations and societal pressure have been increased on the performance of naturally effective crop production system. The emphasis has not only been on raising production but also on considering environmental protection, as well as the quality and wellbeing of the harvests and techniques (PUIG-MONTSERRAT et al., 2017). Therefore, organic farming practices provide an essential substitute for typical farming techniques. Organic farming is a production system in which food is produced without hazardous chemicals, pesticides, contaminants, and non-natural elements (MOSER, 2015). Organic agriculture mitigates human ecological concerns, such as greenhouse gas discharges, biodiversity decline and soil destruction, and also calls attention to food health (CHICIUDEAN et al., 2019).

Different nations have encouraged this move toward organic farming through the promotion of legislation and organic standards (OSEI et al., 2013). Hence, organic food is growing in popularity worldwide, especially in European and North American regions, where sales were up to $90 \%$ of the total consumption of organic food (WILLER et al., 2019). Similarly, a recently published report by Zion Market Research (ZION, 2018) witnessed global organic agricultural growth, which had an approximate market value of USD 124.76 billion in 
2017 and is likely to grow to about USD 323.09 billion by the end of 2024 . These figures indicates a $14.56 \%$ increase in the growth rate between these years.

Several studies have described the behaviour of organic food consumption (AL-SWIDI et al., 2014; KIM et al., 2014; GAKOBO \& JERE, 2016); however, most of these studies focused mainly on developed nations, probably because of the increased demand and sales of organic food in these countries. Although, more organic food is sold in developed nations; however, most organic agriculturists (over $84 \%$ ) are in developing countries. On a regional basis, Asia ranks first in the number of organic producers, accounting for almost $40 \%$ of the total, making it the third-largest market for natural products in the world (LERNOUD \& WILLER, 2019).

Consequently, due to the popularity of organic food, there is a growing need to investigate consumer behaviour in relation to organic products in underdeveloped countries. Therefore, the sample of the present study comprised two developing countries, i.e. Pakistan and Malaysia. Both countries have double-digit agricultural contributions to GDP growth, approximately USD 350 billion nominal GDP each, a large number of agricultural producers, organic agriculture at its initial stage, similar food consumption patterns and most importantly, they are located in the same Asian region. Therefore, they share many commodities and aspire towards a similar organic marketplace (JOUZI et al., 2017). Concurrently, the role of knowledge of healthy food is dominant in increasing the use of organic products in these less developed countries (CHICIUDEAN et al., 2019).

In Pakistan, agriculture plays a significant role and is considered the backbone of the economy. The agricultural sector contributed $18.5 \%$ to GDP and provided employment for $38.5 \%$ of the national labour force (PAKISTAN, 2019b). Most of the farming is performed using traditional methods, including the use of destructive pesticides and chemical fertilisers that affect human health (ASIF et al., 2018). However, in recent times, consumers have moved toward organic food because it offers chemical or pesticide-free food products. To regulate the organic matters and spread awareness among consumers, the National Institute of Organic Agriculture (NIOA) was established during the last decade to work on methods of organic farming and transmit the latest information to smallholders across the country (MUSA et al., 2015). A modest reduction as a result has also been noted in the utilization of hazardous pesticides in
Pakistan. At the same time, organic agricultural land has grown from 6,005 hectares in 2017 to 51,304 hectares in 2019 (WILLER, 2019).

Malaysia, meanwhile, has 7,605,000 hectares of arable land, accounting for $24 \%$ of the total area dedicated to agriculture (KUAN et al., 2017). Similarly, the Malaysian agricultural sector has contributed nearly $12 \%$ to GDP and accounted for $16 \%$ of employment (LEE \& BAHARUDDIN, 2018). The organic food market is at its preliminary phase in Malaysia, but the number of producers has steadily increased since its establishment in the 1990s. The Centre for Environment, Technology and Development, Malaysia (established in 1985), a nongovernmental organisation, has played a pioneering role in identifying traditional agricultural issues and initiating organic farming (SOMASUNDRAM et al., 2016). Currently; however, there is only a small organic food industry locally, and more than $60 \%$ of organic products (comprising grain) are imported into Malaysia (MOHAMAD et al., 2014). Even with the growing demand for organic food, local producers are still unable to meet the escalating need. Figure 1 indicates the conceptual framework of the study.

The scarcity of data in the literature on consumer demand for organic food in both countries (Pakistan and Malaysia) and the high incidence of food safety controversies, such as contaminated meat, milk and vegetables, showed the value of evaluating the demand for local organic products (RIEGER et al., 2016). Furthermore, previous studies primarily compared production levels of conventional and organic agriculture or obstacles to organic farming (AKRAM et al., 2019). Moreover, information on sales figure 1 and perceptions about organic food in developing nations is still lacking (BANATI, 2011).

Hence, it was considered that an investigation into consumer behaviour regarding organic food would provide valuable feedback separately and jointly. Additionally, as long as the consumer's intent towards organic purchases, it can be beneficial to health and natural environment, as well as provide a profitable enterprise. Consequently, this study used the structural equation modelling approach as applied by ASIF et al. (2018) and DE MAGISTRIS \& GRACIA (2008), and performed a comparison between Pakistan and Malaysia by examining the contributory factors that defined consumer intention to purchase natural food items. No such comparative study is available to date. The present study also attempted to establish the moderating role of knowledge on the desire to buy organic produce. 


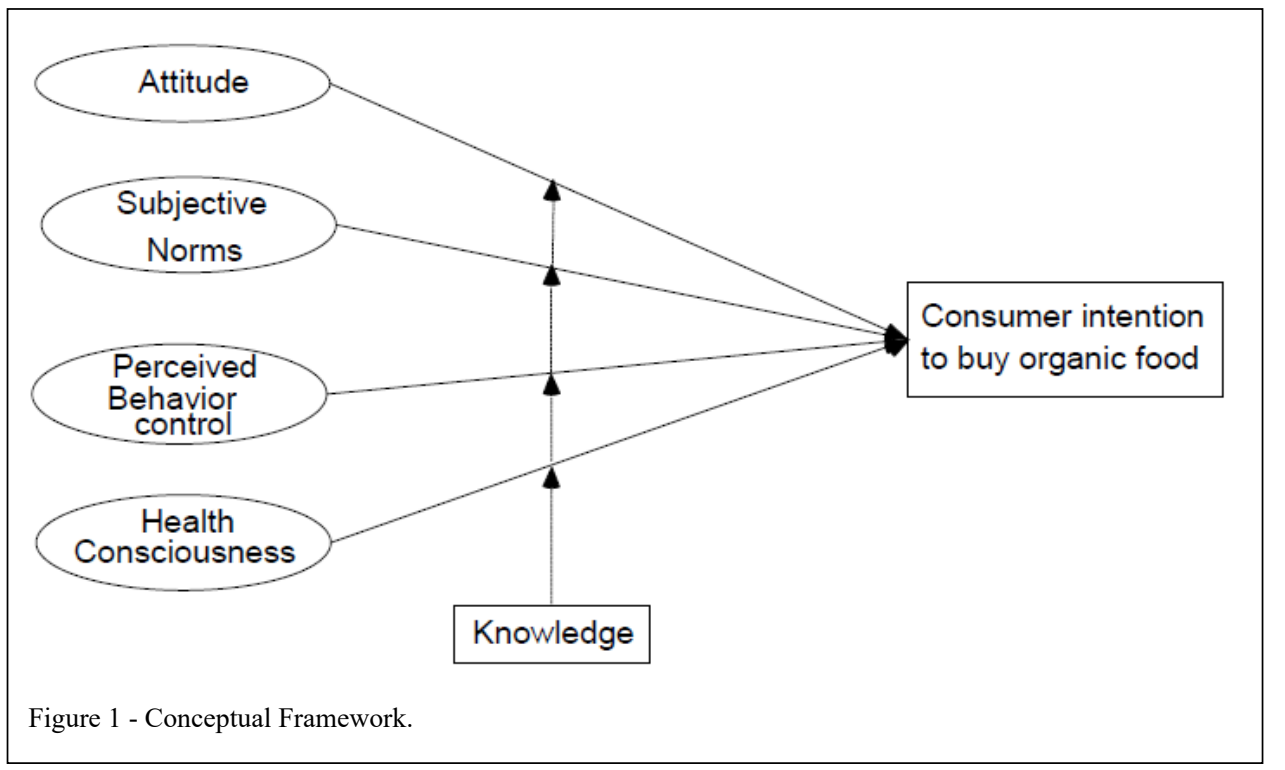

\section{LITERATURE REVIEW AND THE DEVELOPMENT OF HYPOTHESIS}

The literature identified intention as the strategy, choice and willpower of a person to fulfil an action or succeed in achieving a specific objective (HARLAND et al., 1999). The aim of the consumer was to consider a core determining element of his/ her prospective behaviour during the execution of an action. According to the TPB, this behaviour can be predicted through intention with more accuracy when it is influenced by someone (AJZEN \& FISHBEIN, 1980).

The TPB contains three constructs, i.e. attitude toward behaviour, perceived behavioural control (PBC) and subjective norms (SNs). The theory has been well-recognized in social and psychological studies as a rational assessment of consumer purchase intention (SHAH ALAM \& MOHAMED SAYUTI, 2011). The TPB put emphasizes on an individual's conational control since this theory effectively established different types of behavior (OLSEN et al., 2010). In the retail food market, the TPB has been used to illuminate consumers' intention to purchase. The TPB's broad recognition makes it an essential model for analysing customer inclinations in the food sector (KIM et al., 2014). Hence, with the inclusion of the construct of HC in the traditional TPB, the present study examined the organic food purchase intentions of consumers.

Among the three constructs of the TPB, attitude is the first construct and relates to the impacts of an individual's positive and negative emotions while carrying out a particular behaviour. FISHBEIN \& AJZEN (1977) and AJZEN (1991) considered attitude to be significantly linked to purchasing intention. With increased consumption of organic food highlighted in the literature, the present study assumed that attitude regarding its purchase was positive (BIAN \& FORSYTHE, 2012). Moreover, attitude is regarded as an essential predictor of natural food purchase intention (TARKIAINEN \& SUNDQVIST, 2005; HOPPE et al., 2013). Hence, the first hypothesis of attitude in relation to the intention to purchase organic food was tested as:

H1. Attitude positively affects the consumers' intent to buy organic food.

SNs are considered as the second construct of the TPB and they relate to the perception by the individual of the perceived social pressure to approve or disapprove of the conduct in question (FISHBEIN \& AJZEN, 1977). Further, an individual is motivated by how referent groups observe him/her when involved in a particular behaviour.

SNs comprise two interrelated elements: (i) having belief in other people's interests, i.e. how someone else want to see the needs of others are met (normative beliefs), and (ii) outcome evaluations in the shape of positive and negative judgments regarding every single belief (AL-SWIDI et al., 2014). SNs also significantly affect the purchase intention relevant to organic food (TARKIAINEN \& SUNDQVIST, 2005). Thus, the next hypothesis was summarised as:

H2. SNs positively affects the consumers' intent to buy organic food.

PBC is described as "a concept of ease or difficulty to perform a particular behaviour, and it 
is supposed to show the experience along with the expected obstructions and impediments" (AJZEN, 1991). PBC evaluates the willpower of an individual to restrict himself/herself from performing a specific behaviour, and it is dependent on the capabilities and obstacles by which consumers' intentions to purchase are influenced (THOGERSEN, 2009).

The price and availability of organic food are considered the primary obstacles to its acquisition (MAGNUSSON et al., 2001). Organic food is expensive and while some consumers are willing to pay the exceptional prices, many of them are unable to afford these prices because of numerous reasons including periods of stagnation or monetary issues (MILLOCK \& HANSEN, 2002). Thus, the purchasing process of consumers cannot be defined solely by the factor of positive attitude since it involves various other elements in forming a particular purchasing decision.

An individual controls his/her behaviour on his/her own, so a purchase decision is the direct result of a person's belief system (AJZEN, 2015). At the same time, control is an essential contributor in describing the relationship (GOVINDASAMY et al., 2010). Therefore, the PBC hypothesis was summarised as:

H3. PBC positively affects the consumers' intent to buy organic food.

$\mathrm{HC}$ concerns "how much health matters are incorporated into an individual's everyday practices" (JAYANTI \& BURNS, 1998). Health is considered as one of the most significant components when buying organic food products (MICHAELIDOU \& HASSAN, 2008; CHAKRABARTI, 2010; XIE et al., 2015). Consumers of organic food are conscious of the impact of meal consumption and realise the consequences related to chemicals; hence, they choose healthy meals to protect their health (SABA \& MESSINA, 2003).

Organic food products are regarded as more nourishing in comparison to traditional food products (LEA \& WORSLEY, 2005). The findings of ALPHONCE \& ALFNES (2012); ZAGATA (2012); YADAV \& PATHAK (2016); and TENG \& LU (2016) reinforced the important connection between the intention to buy organic food and health cognisance. Hence, based on the above discussion, the following hypothesis was postulated:

H4. HC positively affects the consumers' intent to buy organic food.

In addition, the present study considered the role of knowledge as a moderating variable on consumers' intent to purchase natural food products. For example, buyers and non-buyers are highly conscious of and value data on natural food certification procedures when deciding to make an acquisition (PADEL \& FOSTER, 2005).

Previous findings concluded that the purchase intention toward natural products by consumers could be influenced by their positive attitudes (CHANG \& WU, 2015). These attitudes are drawn from the knowledge that a user has accumulated regarding a product. Moreover, organic food knowledge has a positive impact, whereas a deficiency in knowledge negatively affects natural buying behaviour (SMITH \& PALADINO, 2010). Individuals are thus eager to acknowledge health data from an external source to enhance their well-being practices (PADEL \& FOSTER, 2005).

The context of the present study was less developed countries where the market for organic food was at its preliminary stage. As a result, this research required data on the role of knowledge in the purchase intention toward organic food. Therefore, the following hypothesis was proposed:

H5. Knowledge positively moderates consumers' intent to buy organic food.

\section{MATERIALS AND METHODS}

The level of knowledge of consumers from both countries was assessed before the collection of the quantitative data. For this, a short questionnaire was designed, which consisted of knowledge-based questions that included a specified number of open-ended questions. These questions also explained the motivation factors behind organic food purchases. The questions were sent to 45 respondents, following the universal principle proposed by BROWNE (1995) to evaluate the parameters with 30 or more respondents.

The level of knowledge was reported to be almost the same in both countries and based on this short analysis, a well-defined set of questions was structured to obtain the necessary data. The desired survey document was adapted from a number of relevant studies and drawn up in English.

A small number of differences were observed in the two versions of the questionnaire and were rectified before proceeding further. The questionnaire was designed to evaluate attitude, PBC, SNs and intention to purchase and was adopted from ARVOLA et al. (2008); ASIF et al. (2018); AJZEN (2002); and WANG et al. (2019). The questionnaire on HC and knowledge was adopted from KELLER (1993) and TARKIAINEN \& SUNDQVIST (2005), 
respectively. The measurement of all constructs was on a seven-point Likert scale.

The present study chose four cities (two from each country) for the collection of data, based on their contribution and knowledge about agriculture. In Pakistan, the province of Punjab is the most significant agricultural contributor, and also has the highest literacy rate $(64.7 \%)$ among all the provinces. Therefore, the two most prominent cities in Punjab (Lahore and Faisalabad) were chosen because their residents were assumed to have greater knowledge about the use of organic products (PAKISTAN, 2019a). Similarly, Kuala Lumpur and Kota Kinabalu were selected in Malaysia because both play substantial roles in the production and manufacturing of agricultural products (MALAYSIA, 2019).

The questionnaire was converted into the language of the respective country, i.e. Urdu and Malay. The data were then collected with the assistance of scholars and friends; and subsequently, translated into English to ensure the syntactic equality of the hypotheses (BRISLIN, 1970).

The present research considered and targeted the middle class as it is supposed to be a more stable business driver because of its diversity in demand for commodities and also of the most promotional campaigns are directed to this class. The middle class can also be inspired by and have quick access to information on the importance of natural food (CHIKWECHE \& FLETCHER, 2014). The criteria and selection of middle-class respondents for the list of potential respondents were based on their monthly income levels of more than USD 700 for Pakistan and USD 850 for Malaysia. Furthermore, some support from native researchers was obtained to reach out to the targeted respondents.

The questionnaires were delivered using a variety of media such as email, group emails and social media tools, i.e. WeChat, Facebook and WhatsApp. Questionnaires were also given to several respondents in person as per their convenience for data recovery.

In the case of Pakistan, the questionnaires were sent to approximately 700 respondents. 400 responses were received and 341 were considered for investigation. While, 600 questionnaires were distributed with 312 replies, out of which 280 were considered for analysis in the case of Malaysia. Unanswered feedback forms were excluded, and some outliers were also noted.

The analysis of the study was performed using Analysis of Moment Structures (AMOS) and Statistical Package for Social Science (SPSS) software from IBM. A two-step method was used for the data analysis, as suggested by the earlier study of HAIR et al. (1998). In this process, confirmatory and exploratory factor analyses were conducted to assess and verify the validity and reliability of the measurement model.

\section{RESULTS}

The principal objective of the exploratory factor analysis was to establish the number of predictions that could be estimated (FABRIGAR \& WEGENER, 2011). Next, a structural equation model (SEM) was considered to evaluate the model fit and the hypotheses. The data were first analysed via exploratory factor analysis; then, the cross-loading items were excluded from each country's data set.

The discriminant and convergent validities of the underlying elements were examined by performing a first-order confirmatory factor analysis (CFA). The average variance's square root results for each construct were utilised in the CFA to verify the legitimacy of the construct (FORNELL \& LARCKER, 1981) and with Cronbach's alpha results, convergent validity was assured for both countries.

\section{Pakistan}

The confirmatory factor analysis results are illustrated in Table 1. Cronbach Alpha values for all construct are exceeded the cut-off limit of 0.70 (attitude: 0.793, SNs:0.837, PBC:0.744, HC:0.772, and $\mathrm{KN}: 0.846)$. Furthermore, $\mathrm{CR}$ values are more than the acceptable limit of 0.60 (attitude: $0.884, \mathrm{SN}: 0.876$, PBC:0.905, HC:0.793, and KN:0.921). Similarly, the estimated AVE values also exceeding the prescribed range of 0.50 (attitude: 0.571, SN:0.594, PBC:0.645, $\mathrm{HC}: 0.523$, and $\mathrm{KN}: 0.694)$.

The demographic features of the respondents are shown via the results of the descriptive analysis in Table 2 . The sample comprised 205 males $(60.1 \%)$ and 136 females $(39.9 \%)$. With regard to the level of education, $21.1 \%$ of the respondents were PhD holders, $46.3 \%$ had master's degrees and $32.6 \%$ were bachelor's degree holders.

Four categories of absolute fit indices were used to evaluate the model fit in the present study. They were root mean residual (RMR), adjusted goodness-of-fit index (AGFI), root mean square error of approximation (RMSEA) and goodness-offit index (GFI). The following results were obtained after the CFA: RMR $=0.024$ (cut-off: value nearer to zero); GFI $=0.923$ (cut-off: 0.90 ); AGFI $=0.836$ (cutoff: 0.80 ) and RMSEA $=0.059$ (cut-off: 0.08). 
Table 1 - Results of validity measures and CFA.

\begin{tabular}{|c|c|c|c|c|c|c|c|c|c|}
\hline \multicolumn{5}{|c|}{ 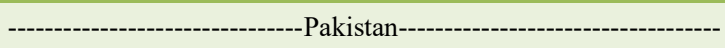 } & \multicolumn{5}{|c|}{---------------------------------Malaysia---------------------------------- } \\
\hline Items & Loadings & $\begin{array}{l}\text { Cronbach's } \\
\text { Alpha }\end{array}$ & $\mathrm{CR}$ & AVE & Items & Loadings & $\begin{array}{l}\text { Cronbach's } \\
\text { Alpha }\end{array}$ & CR & AVE \\
\hline Att1 & 0.77 & \multirow{4}{*}{0.793} & \multirow{4}{*}{0.884} & \multirow{4}{*}{0.571} & At2 & 0.79 & \multirow{4}{*}{0.768} & \multirow{4}{*}{0.872} & \multirow{4}{*}{0.532} \\
\hline Att2 & 0.80 & & & & At3 & 0.86 & & & \\
\hline Att3 & 0.74 & & & & At 4 & 0.82 & & & \\
\hline Att4 & 0.82 & & & & At5 & 0.77 & & & \\
\hline SN1 & 0.69 & \multirow{4}{*}{0.837} & \multirow{4}{*}{0.876} & \multirow{4}{*}{0.594} & SN1 & 0.86 & \multirow{4}{*}{0.834} & \multirow{4}{*}{0.827} & \multirow{4}{*}{0.659} \\
\hline SN2 & 0.73 & & & & SN2 & 0.81 & & & \\
\hline SN3 & 0.79 & & & & SN3 & 0.83 & & & \\
\hline SN4 & 0.82 & & & & SN4 & 0.75 & & & \\
\hline PBC2 & 0.85 & & & & PBC1 & 0.82 & & & \\
\hline PBC3 & 0.88 & 0.744 & 0.905 & 0.645 & PBC2 & 0.73 & 0.780 & 0.774 & 0.554 \\
\hline $\mathrm{HC} 1$ & 0.76 & \multirow{3}{*}{0.772} & \multirow{3}{*}{0.793} & \multirow{3}{*}{0.523} & $\mathrm{HC} 1$ & 0.85 & \multirow{3}{*}{0.732} & \multirow{3}{*}{0.786} & \multirow{3}{*}{0.521} \\
\hline $\mathrm{HC} 2$ & 0.71 & & & & $\mathrm{HC} 2$ & 0.74 & & & \\
\hline $\mathrm{HC} 3$ & 0.73 & & & & $\mathrm{HC} 3$ & 0.70 & & & \\
\hline KN1 & 0.84 & \multirow{3}{*}{0.846} & \multirow{3}{*}{0.921} & \multirow{3}{*}{0.694} & KN1 & 0.83 & \multirow{3}{*}{0.705} & \multirow{3}{*}{0.743} & \multirow{3}{*}{0.538} \\
\hline KN2 & 0.90 & & & & KN2 & 0.79 & & & \\
\hline KN3 & 0.81 & & & & KN3 & 0.72 & & & \\
\hline I1 & 0.67 & \multirow{3}{*}{0.871} & \multirow{3}{*}{0.813} & \multirow{3}{*}{0.621} & IP1 & 0.77 & \multirow{3}{*}{0.721} & \multirow{3}{*}{0.791} & \multirow{3}{*}{0.562} \\
\hline I2 & 0.89 & & & & IP2 & 0.80 & & & \\
\hline $\mathrm{I} 3$ & 0.75 & & & & IP3 & 0.71 & & & \\
\hline
\end{tabular}

Note: Att = Attitude; SNs = Subjective Norms; $\mathrm{PBC}=$ Perceived Behavioural Control; HC = Health Consciousness; KN = Knowledge; I $=$ Intention to Purchase; $\mathrm{CR}=$ Composite Reliability; AVE: Average Variance Explained.

This test was carried out according to the recommendations of HAIR et al. (2013) and HU \& BENTLER (1999). Hence, the validity assertion of the items was provided through the model fit values, and structural model fit was used for the hypotheses results. The model fit values were presented as: Tucker-Lewis index $(\mathrm{TLI})=0.901 ; \mathrm{RMR}=0.031$; $\mathrm{CFI}=0.918$ and $\mathrm{RMSEA}=0.062$.

To observe the moderating behaviour of the knowledge variable, the terms of the interaction were established through the multiplication of the combined constructs of attitude, SNs, health consciousness and PBC with the compound knowledge construct. The SEM model was utilized to conduct the hypotheses tests, and their results are illustrated in Table 3.

The results disclosed that the SNs were associated significantly with the intent to buy, with an estimate of 0.132 at a significance level of 0.000 . The SNs' interaction term was also significant with consumers' intention to purchase, with an estimated value of 0.154 . However, $\mathrm{PBC}$ and its interaction terms were non-significant predictors of organic food purchase intent, which indicated a lack of interaction.

Moreover, attitude was a key predictor of consumer purchase intentions with an estimation of 0.171 at a significance level of 0.001 . In addition, it interacted extensively with the intent to purchase, as shown by an estimate of 0.117 .

Lastly, health consciousness was substantially correlated with the purchase intent of the consumer, with an estimate of 0.189 at a significance level of 0.007 , and its interaction term was also a significant predictor of purchase intention, with a value of 0.202 . The overall ability of the model was explained by the assessment of $\mathrm{R}$ squared, which was $84 \%$. 
Table 2 - Sociodemographic profile.

\begin{tabular}{|c|c|c|c|c|c|}
\hline & \multicolumn{3}{|c|}{ 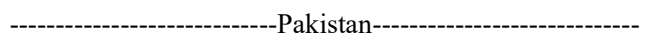 } & \multicolumn{2}{|c|}{---------------------Malaysia------------------- } \\
\hline & \multicolumn{3}{|c|}{---------------------------------N } & \multicolumn{2}{|c|}{--------------------N = 280-------------------- } \\
\hline Characteristics & Variables & Frequency & $\%$ & Frequency & $\%$ \\
\hline \multirow{2}{*}{ Gender } & Male & 205 & 60.1 & 185 & 66.1 \\
\hline & Female & 136 & 39.9 & 95 & 33.9 \\
\hline \multirow{3}{*}{ Education level } & $\mathrm{PhD}$ & 72 & 21.1 & 83 & 29.7 \\
\hline & Master's & 158 & 46.3 & 76 & 27.1 \\
\hline & Bachelor's & 111 & 32.6 & 121 & 43.2 \\
\hline \multirow{3}{*}{ Profession } & Firm employee & 195 & 57.1 & 110 & 39.3 \\
\hline & Civil servant & 110 & 32.3 & 125 & 44.6 \\
\hline & Housewife & 36 & 10.6 & 45 & 16.1 \\
\hline \multirow{3}{*}{$\begin{array}{l}\text { Household monthly } \\
\text { income (USD) }\end{array}$} & $650-900$ & 169 & 49.5 & 115 & 41.1 \\
\hline & $900-140$ & 156 & 45.8 & 141 & 50.3 \\
\hline & $>1400$ & 16 & 4.7 & 24 & 8.6 \\
\hline
\end{tabular}

Malaysia

The Cronbach Alpha values for all construct are exceeded the cut-off limit of 0.70 (attitude: 0.768 , SNs:0.834, PBC:0.780, HC:0.732, and KN:0.705). Furthermore, $\mathrm{CR}$ values are more than the acceptable limit of 0.60 (attitude: $0.872, \mathrm{SN}: 0.827, \mathrm{PBC}: 0.774$, HC:0.786, and KN:0.743). Similarly, the estimated AVE values also exceeding the prescribed range of 0.50 (attitude: $0.532, \mathrm{SN}: 0.659, \mathrm{PBC}: 0.554$, $\mathrm{HC}: 0.521$, and $\mathrm{KN}: 0.538$ ).

The demographic attributes of the respondents in Malaysia are presented in Table 2. The respondents comprised $66.1 \%$ males and $33.9 \%$ females. As for the level of education of the respondents, $29.7 \%$ were $\mathrm{PhD}$ holders, $27.1 \%$ had master's degrees and $43.2 \%$ were holders of bachelor's degrees.

The following results were attained after the CFA: RMR $=0.031$ (cut-off: value nearer to zero); GFI $=0.902$ (cut-off: 0.90 ); AGFI $=0.817$ (cut-off: 0.80 ) and RMSEA $=0.064$ (cut-off: 0.08 ). The model fit values were presented as: $\mathrm{TLI}=0.847$; $\mathrm{RMR}=$ 0.027 ; CFI $=0.902$ and $\mathrm{RMSEA}=0.056$.

The direct and moderating results for Malaysia are presented in Table 3. The SNs were significantly associated with the purchase intent with an estimate of 0.097 at a significance level of 0.001 . The SNs' interaction term was also significant with the consumer's intent to purchase, with an estimated value of 0.176 .
The PBC and its interaction terms were non-significant predictors of organic food purchase intent, which disclosed a lack of interaction. Like Pakistan, the results for $\mathrm{PBC}$ and its interaction terms for Malaysia were the same, which suggested the non-existence of a relationship. Furthermore, attitude was a significant predictor of purchase intent with an estimate of 0.193 at a significance level of 0.002 ; it also interacted significantly, with an estimation of 0.229 .

Finally, $\mathrm{HC}$ was significantly correlated with a value of 0.187 at a significance level of 0.015 . In addition, the interaction term was considerably associated with the intent to buy organic food, with an estimate of 0.209 .

\section{DISCUSSION AND CONCLUSION}

The present study aimed to determine the different aspects that stimulated consumers' intent to purchase organic food. In the existing literature, most researches were conducted in relation to developed countries or where organic sales were significant. However, developing countries like Pakistan and Malaysia, with their substantial agricultural contributions and being at the initial stage of organic agriculture, have not been studied. The purpose of this study, therefore, was to fill this gap by evaluating consumer purchasing intentions toward organic food in Pakistan and Malaysia, with 
Table 3 - Hypothesized direct outcomes.

\begin{tabular}{|c|c|c|c|c|c|c|c|}
\hline & & -------. & --------Pakista & -------------- & -------. & ------Malaysia & --------------- \\
\hline Hypothesis & Description & Value & Significance & Conclusion & Value & Significance & Conclusion \\
\hline H1 & $\begin{array}{l}\text { Attitude positively affects } \\
\text { consumers' intent to buy } \\
\text { organic food }\end{array}$ & 0.171 & 0.001 & Endorsed & 0.193 & 0.002 & Endorsed \\
\hline $\mathrm{H} 2$ & $\begin{array}{l}\text { SNs positively affect } \\
\text { consumers' intent to buy } \\
\text { organic food }\end{array}$ & 0.132 & 0.000 & Endorsed & 0.097 & 0.001 & Endorsed \\
\hline $\mathrm{H} 3$ & $\begin{array}{l}\text { PBC positively affects } \\
\text { consumers' intent to buy } \\
\text { organic food }\end{array}$ & 0.142 & 0.274 & $\begin{array}{c}\text { Not } \\
\text { endorsed }\end{array}$ & 0.285 & 0.278 & $\begin{array}{c}\text { Not } \\
\text { endorsed }\end{array}$ \\
\hline $\mathrm{H} 4$ & $\begin{array}{c}\text { HC positively affects } \\
\text { consumers' intent to buy } \\
\text { organic food }\end{array}$ & 0.189 & 0.007 & Endorsed & 0.187 & 0.015 & Endorsed \\
\hline H5-I & $\begin{array}{c}\text { Knowledge positively } \\
\text { moderates the relationship } \\
\text { between attitude and intent to } \\
\text { buy }\end{array}$ & 0.117 & 0.003 & Endorsed & 0.229 & 0.000 & Endorsed \\
\hline H5-II & $\begin{array}{l}\text { Knowledge positively } \\
\text { moderates the relationship } \\
\text { between SNs and intent to } \\
\text { buy }\end{array}$ & 0.154 & 0.046 & Endorsed & 0.176 & 0.002 & Endorsed \\
\hline H5-III & $\begin{array}{l}\text { Knowledge positively } \\
\text { moderates the relationship } \\
\text { between PBC and purchase } \\
\text { intention }\end{array}$ & 0.178 & 0.362 & $\begin{array}{c}\text { Not } \\
\text { endorsed }\end{array}$ & 0.352 & 0.431 & $\begin{array}{c}\text { Not } \\
\text { endorsed }\end{array}$ \\
\hline H5-IV & $\begin{array}{l}\text { Knowledge positively } \\
\text { moderates the relationship } \\
\text { between } \mathrm{HC} \text { and intent to } \\
\text { buy }\end{array}$ & 0.202 & 0.020 & Endorsed & 0.209 & 0.004 & Endorsed \\
\hline
\end{tabular}

the moderating variable of knowledge, in order to arrive at conclusions based on comparisons made between these countries. In addition, the results identified the factors linked to the purchase intent of consumers in both countries, which will provide constructive material for industry participants, such as the promotion of organic products in the future.

The main results revealed that $\mathrm{SNs}, \mathrm{HC}$, attitude and their knowledge interaction terms were essential elements in influencing consumer intention toward organic food. However, the interaction terms of knowledge for PBC were insignificant. The intensity of the underlying variables differed between the two countries. The SNs were significant in both countries, and these outcomes supported the finding of AL-SWIDI et al., (2014), that is, when knowledge of organic brands increases, then the intent of consumers becomes a social norm. This finding means that human beings are probably influenced by the others' perceptions (DE MAYA et al., 2011). The interaction terms of knowledge also interacted well, and these findings were consistent with the studies of GIL \& SOLER (2006) and WANG et al. (2019). The SNs can be set up via different social media channels by providing detailed information, which is now instantly available due to technological advancements. Social media applications also deliver data faster, which increases the value of SNs as predictors of consumers' intention to purchase. However, less knowledge about organic food is entirely different perception.

Results on attitude were aligned with CHEN (2007) and MOHD SUKI (2016), who indicated that the potential for consumers to purchase natural food increased when there was a positive attitude. Attitude was the second-most dominant variable in the intent to purchase in both countries. 
Furthermore, results for $\mathrm{HC}$ established that safety and health issues have an influential role in the intent of consumers of organic foods. These results followed the studies of (KRYSTALLIS \& CHRYSSOHOIDIS, 2005; ARVOLA et al., 2008; DE MAGISTRIS \& GRACIA, 2008; ZAGATA, 2012; GRUBOR \& DJOKIC, 2016; MISRA \& SINGH, 2016; ASIF et al., 2018). The HC contributed the most to purchase intention in Pakistan, while it placed third in the case of Malaysia.

The role of PBC in the intent to purchase organic items was insignificant in both countries. The reason for this finding may be the absence of assets or specific control to exhibit explicit conduct. Results specified that even with a positive attitude, significant SNs and HC about organic food, obstacles still existed with regard to purchase intention (YAZDANPANAH \& FOROUZANI, 2015). The main reason for this could be family systems, which were combined in both countries. That is, centralization of decision-making in the hands of a leading family member, which led to other family members following his/her intention.

In conclusion, by identifying the moderating role of knowledge in the purchase intent of consumers of organic food, which is allied with the investigations of GIL \& SOLER (2006) and WANG et al. (2019), the present study make a significant contribution to the current body of knowledge. The current study examined two developing countries and found only minor differences in the factors motivating the intent to purchase organic food. These coinciding views were due to the similar circumstances that these nations experience, for instance, sharing the same continent with similar market structures.

The findings of study suggested that aggressive marketing strategies are needed to improve awareness of the benefits of organic food consumption among purchasers in both Pakistan and Malaysia. The demand for natural food products could be improved by means of appropriate educational, health and food safety materials to encourage consumers to use certified organic foodstuff, for example, which could influence the purchasing intention and increase sales. Furthermore, because no chemicals, pesticides or additives are used, organic food is known to be safer than traditional food. Thus, it should be conveyed in marketing campaigns that production methods for organic products are distinct from those for conventional food.

Both countries rely on agriculture; thus, agricultural production of natural food products would be beneficial to health and the environment and would also boost the economy. It should also be noted that; although, no direct relationships were developed in this study with respect to environmental aspects, natural food production supports the ecosystem.

The present study further found that not all consumers could afford to take advantage of organic food. Governments should; therefore, play a functional role in alleviating natural food prices by subsidising small farmers and enhancing sustainable organic farming, which will also influence the purchasing behaviour of low-income consumers.

\section{LIMITATIONS}

The present study faced several limitations. Only regular consumers of organic food were considered; therefore, future studies should involve both regular and non-regular customers to gain more well-rounded results. Moreover, the collection of data was based on middle-class income as a criterion. In addition, only the cities of Lahore and Faisalabad in Pakistan, and Kuala Lumpur and Kota Kinabalu in Malaysia, were considered. Future studies should use other income categories and collect data from different areas to broaden understanding, as the results of the present study did not apply to all income groups or to other parts of these countries.

\section{BIOETHICS AND BIOSSECURITY COMMITTEE APPROVAL}

We authors of the article entitled " Factors affecting consumer preferences in the purchase intention toward organic food and the moderating role of knowledge" declared, for all due purposes, the project that gave rise to the present data of the same has not been submitted for evaluation to the Ethics Committee of the University /Research Institute "Northeast Forestry University", but we are aware of the contents of Resolution No. 466, of December 12, 2012 of the Brazilian National Health Council "http:// conselho.saude.gov.br/resolucoes/2012/Reso466. pdf" if it involves human.

Thus, the authors assume full responsibility for the presented data and are available for possible questions, should they be required by the competent authorities.

\section{ACKNOWLEDGMENTS}

We would like to thank College of Economics and Management, Northeast Forestry University, Harbin for their continuous support in the conduct of this study.

\section{FINANCIAL SUPPORT}

We did not receive any financial support. 


\section{DECLARATION OF CONFLICT OF INTERESTS}

The authors declare no conflict of interest. The founding sponsors had no role in the design of the study; in the collection, analyses, or interpretation of data; in the writing of the manuscript, and in the decision to publish the results.

\section{AUTHORS' CONTRIBUTIONS}

All authors contributed equally for the conception and writing of the manuscript. All authors critically revised the manuscript and approved of the final version.

\section{REFERENCES}

AJZEN, I. The theory of planned behavior. Organizational behavior and human decision processes, v.50, n.2, p.179211. 1991. Available from: <https://doi.org/10.1016/07495978(91)90020-T>. Accessed: Jun. 22, 2019.

AJZEN, I. Perceived behavioral control, self-efficacy, locus of control, and the theory of planned behavior 1. Journal of applied social psychology, v.32, n.4, p.665-683. 2002. Available from: $<$ https://doi.org/10.1111/j.1559-1816.2002.tb00236.x>. Accessed: Jun. 22, 2019.

AJZEN, I. The theory of planned behaviour is alive and well, and not ready to retire: a commentary on Sniehotta, Presseau, and Araújo-Soares. Health psychology review, v.9, n.2, p.131-137. 2015. Available from: $<$ https://doi.org/10.1080/17437199.2014.88 3474>. Accessed: Jun. 22, 2019.

AJZEN, I.; M. FISHBEIN. Understanding attitudes and predicting social behaviour. 155 Middlesex Turnpike Burlington, MA 01803. USA. Scienceopen.com. 1980. Available from: <https:/Www.scienceopen.com document? vid=c20c4174-d8dc-428d-b352-280b05 eacdf7>. Accessed: Jun. 22, 2019.

AKRAM, M. W., et al. An Assessment of Economic Viability of Organic Farming in Pakistan. Custos e Agronegocio online, v.15, n.1, p.141-169. 2019. Available from: <http://www. custoseagronegocioonline.com.br/numero1v15/OK\%207\%20 farming\%20english.pdf>. Accessed: Mar. 10, 2019.

AL-SWIDI, A., et al. The role of subjective norms in theory of planned behavior in the context of organic food consumption. British Food Journal, v.116, n.10, p.1561-1580. 2014. Available from: <https://doi.org/10.1108/BFJ-05-2013-0105>. Accessed: Mar. 10, 2019

ALPHONCE, R.; F. ALFNES. Consumer willingness to pay for food safety in Tanzania: an incentive-aligned conjoint analysis. International journal of consumer studies, v.36, n.4, p.394-400. 2012. Available from: <https://doi.org/10.1111 /j.1470-6431.2011.01067.x>. Accessed: Mar. 10, 2019.

ARVOLA, A., et al. Predicting intentions to purchase organic food: The role of affective and moral attitudes in the Theory of Planned Behaviour. Appetite, v.50, n.2-3, p.443-454. 2008. Available from: <https://doi.org/10.1016/j.appet.2007.09.010>. Accessed: Feb. 10, 2019
ASIF, M., et al. Determinant factors influencing organic food purchase intention and the moderating role of awareness: A comparative analysis. Food Quality and preference, v.63, p.144-150. 2018. Available from: https://doi.org/10.1016/j. foodqual.2017.08.006. Accessed: Feb. 10, 2019.

BANATI, D. Consumer response to food scandals and scares Trends in Food Science \& Technology, v.22, n.2-3, p.56-60. 2011. Available from: <https://doi.org/10.1016/j.tifs.2010.12.007> Accessed: May, 15, 2019.

BIAN, Q.; S. FORSYTHE. Purchase intention for luxury brands: A cross cultural comparison. Journal of Business Research, v.65, n.10, p.1443-1451. 2012. Available from: <https://doi. org/10.1016/j.jbusres.2011.10.010>. Accessed: May, 15, 2019.

BRISLIN, R. W. Back-translation for cross-cultural research. Journal of cross-cultural psychology, v.1, n.3, p.185-216. 1970. Available from: <https://doi.org/10.1177/135910457000100301>. Accessed: Jul. 15, 2019.

BROWNE, R. H. On the use of a pilot sample for sample size determination. Statistics in medicine, v.14, n.17, p.1933-1940. 1995. Available from: <https://doi.org/10.1002/sim.4780141709>. Accessed: Jul. 15, 2019.

CHAKRABARTI, S. Factors influencing organic food purchase in India-expert survey insights. British Food Journal, v.112, n.8, p.902-915. 2010. Available from: <https://doi. org/10.1108/00070701011067497>. Accessed: Jul. 15, 2019.

CHANG, M.-C.; C.-C. WU. The effect of message framing on pro-environmental behavior intentions: An information processing view. British Food Journal, v. 117, n.1, p.339-357. 2015. Available from: <https://doi.org/10.1108/BFJ-09-2013-0247>. Accessed: Jul. 15, 2019

CHEN, M.-F. Consumer attitudes and purchase intentions in relation to organic foods in Taiwan: Moderating effects of foodrelated personality traits. Food Quality and preference, v.18, n.7, p.1008-1021. 2007. Available from: <https://doi.org/10.1016/j. foodqual.2007.04.004>. Accessed: Aug. 15, 2019.

CHICIUDEAN, G. O., et al. Organic Food Consumers and Purchase Intention: A Case Study in Romania. Agronomy, v.9, n.3, p.145. 2019. Available from: $<$ https://doi.org/10.3390/ agronomy9030145>. Accessed: Sep 05, 2019.

CHIKWECHE, T.; R. FLETCHER. Marketing to the "middle of the pyramid" in emerging markets using a social network perspective: Evidence from Africa. International Journal of Emerging Markets, v.9, n.3, p.400-423. 2014. Available from: <https://doi.org/10.1108/IJoEM-05-2013-0090>. Accessed: Aug. $15,2019$.

DE MAGISTRIS, T.; A. GRACIA. The decision to buy organic food products in Southern Italy. British Food Journal, v.110, n.9, p.929-947. 2008. Available from: <https://doi. org/10.1108/00070700810900620>. Accessed: Aug. 01, 2019.

DE MAYA, S. R., et al. Organic food consumption in Europe: International segmentation based on value system differences. Ecological Economics, v.70, n.10, p.1767-1775. 2011. Available from: $\quad<$ https://doi.org/10.1016/j.ecolecon.2011.04.019>. Accessed: Aug. 01, 2019. 
FABRIGAR, L. R.; D. T. WEGENER. Exploratory factor analysis. New York: Oxford University Press. 2011. Available from: $\quad<$ https://books.google.es/books?hl=en\&lr=\&id=DSppAg AAQBAJ\&oi $=$ fnd \&pg $=$ PP $1 \& d q=$ FABRIGAR,+ L.+ R $\% 3 B+D$. + T.+WEGENER.+Exploratory+factor+analysis:+Oxford+Unive rsity+Press. $+2011 \&$ ots=alMfTQa8Wu\&sig=7XIGXtzmW3R1 zuGElFFlUw8wEs\&redir_esc $=\mathrm{y} \# \mathrm{v}=$ onepage \&q\&f=false $158 \mathrm{p}>$. Accessed: Aug. 01, 2019.

FISHBEIN, M.; I. AJZEN. Belief, attitude, intention, and behavior: An introduction to theory and research. 1977. Available from: $<$ https://philarchive.org/archive/FISBAI $>$. Accessed: Aug. 01, 2019.

FORNELL, C.; D. F. LARCKER. Evaluating structural equation models with unobservable variables and measurement error. Journal of marketing research, v.18, n.1, p.39-50. 1981. Available from: <https://doi.org/10.1177\%2F002224378101800104> Accessed: Aug. 01, 2019.

GAKOBO, T. W.; M. G. JERE. An application of the theory of planned behaviour to predict intention to consume African indigenous foods in Kenya. British Food Journal, v.118, n.5, p.1268-1280. 2016. Available from: <https://doi.org/10.1108/BFJ10-2015-0344>. Accessed: Sep 05, 2019.

GIL, J. M.; F. SOLER. Knowledge and willingness to pay for organic food in Spain: Evidence from experimental auctions. Acta Agriculturae Scand Section C, v.3, n.3-4, p.109-124. 2006 Available from: <https://doi.org/10.1080/16507540601127656>. Accessed: Sep. 05, 2019.

GOVINDASAMY, R., et al. Hispanic consumers perceptions towards organically grown ethnic produce: A logistic analysis. African Journal of Agricultural Research, v.5, n.24, p.34643469. 2010. Available from: <http://www.academicjournals.org/ app/webroot/article/article1380806244_Govindasamy\%20et\%20 al.pdf $>$. Accessed: Sep. 05, 2019.

GRUBOR, A.; N. DJOKIC. Organic food consumer profile in the Republic of Serbia. British Food Journal, v.118, n.1, p.164-182. 2016. Available from: <https://doi.org/10.1108/BFJ-06-20150225>. Accessed: Sep. 05, 2019.

HAIR, J., et al. Multivariate Data Analysis. United States: Prentice Hall Upper Saddle River. NJ:. Vol. 5: 207-219 p. 1998.

HAIR, J. F., et al. Partial least squares structural equation modeling: Rigorous applications, better results and higher acceptance. Long range planning, v.46, n.1-2, p.1-12. 2013. Available from: $<$ https://ssrn.com/abstract=2233795>. Accessed: Sep. 05, 2019.

HARLAND, P., et al. Explaining proenvironmental intention and behavior by personal norms and the Theory of Planned Behavior 1. Journal of applied social psychology, v.29, n.12, p.2505-2528. 1999. Available from: $<$ https://doi.org/10.1111/j.1559-1816.1999. tb00123.x>. Accessed: Jun. 17, 2019.

HOPPE, A., et al. Consumer behaviour towards organic food in porto alegre: an application of the theory of planned behaviour. Revista de Economia e Sociologia Rural, v.51, n.1, p.6990. 2013. Available from: <http://dx.doi.org/10.1590/S010320032013000100004>. Accessed: Jun. 17, 2019.

HU, L. T.; P. M. BENTLER. Cutoff criteria for fit indexes in covariance structure analysis: Conventional criteria versus new alternatives. Structural equation modeling: a multidisciplinary journal, v.6, n.1, p.1-55. 1999. Available from: <https://doi. org/10.1080/10705519909540118>. Accessed: Apr. 17, 2019.

JAYANTI, R. K.; A. C. BURNS. The antecedents of preventive health care behavior: An empirical study. Journal of the academy of marketing science, v.26, n.1, p.6-15. 1998. Available from: $<$ https://doi.org/10.1177\%2F0092070398261002>. Accessed: Jun. 17,2019

JOUZI, Z., et al. Organic farming and small-scale farmers: Main opportunities and challenges. Ecological Economics, v.132, p.144-154. 2017. Available from. Accessed: Jun. 17, 2019.

KELLER, K. L. Conceptualizing, measuring, and managing customer-based brand equity. Journal of marketing, v.57, n.1, p.1-22. 1993. Available from: <https://doi.org/10.1177\% 2F002224299305700101>. Accessed: Jun. 17, 2019.

KIM, Y. G., et al. Application of the theory of planned behavior to genetically modified foods: Moderating effects of food technology neophobia. Food research international, v.62, p.947-954. 2014. Available from: <https://doi.org/10.1016/j.foodres.2014.03.057>. Accessed: Jul. 20, 2019.

KRYSTALLIS, A.; G. CHRYSSOHOIDIS. Consumers' willingness to pay for organic food: Factors that affect it and variation per organic product type. British Food Journal, v.107, n.5, p.320-343. 2005. Available from: <https://doi. org/10.1108/00070700510596901>. Accessed: Jul. 20, 2019.

KUAN, C.-H., et al. Comparison of the microbiological quality and safety between conventional and organic vegetables sold in Malaysia. Frontiers in microbiology, v.8, p.1433. 2017. Available from: <https://doi.org/10.3389/fmicb.2017.01433>. Accessed: Jul. 20,2019 .

LEA, E.; T. WORSLEY. Australians' organic food beliefs, demographics and values. British Food Journal, v.107, n.11, p.855-869. 2005. Available from: $<$ https://doi. org/10.1108/00070700510629797>. Accessed: Jul. 20, 2019.

LEE, W. C.; A. H. BAHARUDDIN. Impacts of Climate Change on Agriculture in Malaysia. In: (Ed.). The Impact of Climate Change on Our Life: Springer, 2018. Impacts of Climate Change on Agriculture in Malaysia, p.179-195

LERNOUD, J.; H. WILLER. Organic Agriculture Worldwide: Key results from the FiBL survey on organic agriculture worldwide 2019 Part 3: Organic agriculture in the regions. 2019. Available from: $<$ https:// www.organic-world.net/fileadmin/documents/yearbook/2019/FiBL2019-Regions-2017.pdf>. Accessed: Oct. 16, 2019.

MAGNUSSON, M. K., et al. Attitudes towards organic foods among Swedish consumers. British Food Journal, v.103, n.3, p.209-227. 2001. Available from: <https://doi. org/10.1108/00070700110386755>. Accessed: Oct. 16, 2019.

MALAYSIA. Department of Statistics, Federal Government Administrative Centre, Malaysia. 2019. Available from: $<$ https:// www.dosm.gov.my/v1/>. Accessed: Jun. 16, 2019.

MICHAELIDOU, N.; L. M. HASSAN. The role of health consciousness, food safety concern and ethical identity on attitudes and intentions towards organic food. International journal of consumer studies, v.32, n.2, p.163-170. 2008. Available from: < https://doi.org/1 0.1111/j.1470-6431.2007.00619.x>. Accessed: Oct. 16, 2019. 
MILLOCK, K.; L. G. HANSEN. Willingness to pay for organic foods: a comparison between survey data and panel data from Denmark. 2002. Available from: <https://mpra.ub.uni-muenchen. de/id/eprint/47588>. Accessed: Oct. 16, 2019.

MISRA, R.; D. SINGH. An analysis of factors affecting growth of organic food: Perception of consumers in Delhi-NCR (India). British Food Journal, v.118, n.9, p.2308-2325. 2016. Available from: <https://doi.org/10.1108/BFJ-02-2016-0080>. Accessed: Oct. 16, 2019 .

MOHAMAD, S. S., et al. Organic food consumption among urban consumers: Preliminary results. Procedia-Social and Behavioral Sciences, v.130, p.509-514. 2014. Available from: <https://doi. org/10.1016/j.sbspro.2014.04.059>. Accessed: Sep. 22, 2019.

MOHD SUKI, N. Green product purchase intention: impact of green brands, attitude, and knowledge. British Food Journal v.118, n.12, p.2893-2910. 2016. Available from: <https://doi. org/10.1108/BFJ-06-2016-0295>. Accessed: Sep. 22, 2019.

MOSER, A. K. Thinking green, buying green? Drivers of proenvironmental purchasing behavior. Journal of consumer marketing. 2015.

MUSA, M., et al. Status and future prospect of organic agriculture for safe food security in SAARC countries.: SAARC Agriculture Centre (SAC). Dhaka, Bangladesh: 357-360 p. 2015.

OLSEN, N. V., et al. Predicting consumers' intention to consume ready-to-eat meals. The role of moral attitude. Appetite, v.55, n.3, p.534-539. 2010. Available from: <https://doi.org/10.1016/j. appet.2010.08.016>. Accessed: Sep. 22, 2019

OSEI, S., et al. A study of student perception of organic agriculture and organic foods. Ghanaian Journal of Animal Science, v.7, n.2, p.142-150. 2013. Available from: $<$ https://www.researchgate net/publication/262562164 A STUDY OF STUDENT PERCEPTION OF ORGANIC AGRICULTURE AND ORGANIC_FOODS $>$. Accessed: Sep. 22, 2019.

PADEL, S.; C. FOSTER. Exploring the gap between attitudes and behaviour: Understanding why consumers buy or do not buy organic food. British Food Journal, v.107, n.8, p.606-625. 2005. Available from: <https://doi.org/10.1108/00070700510611002>. Accessed: Sep. 22, 2019.

PAKISTAN. Pakistan Bureau of Statistics. Agriculture Statistics. Government of Pakistan. 2019a. Available from: <http://www.pbs. gov.pk/content/agriculture-statistics>. Accessed: Apr. 26, 2019.

PAKISTAN. Pakistan economic survey. Pakistan: Ministry of Finance, Government of Pakistan. 2019b. Available from: <http:/ www.finance.gov.pk/>. Accessed: Apr. 26, 2019.

PUIG-MONTSERRAT, X., et al. Effects of organic and conventional crop management on vineyard biodiversity. Agriculture, ecosystems \& environment, v.243, p.19-26. 2017. Available from: <https://doi.org/10.1016/j.agee.2017.04.005>. Accessed: Apr. 26, 2019.

RIEGER, J., et al. Food scandals, media attention and habit persistence among desensitised meat consumers. Food Policy v.64, p.82-92. 2016. Available from: <https://doi.org/10.1016/j. foodpol.2016.09.005>. Accessed: Apr. 26, 2019
SABA, A.; F. MESSINA. Attitudes towards organic foods and risk/ benefit perception associated with pesticides. Food Quality and preference, v.14, n.8, p.637-645. 2003. Available from: $<$ https://doi org/10.1016/S0950-3293(02)00188-X>. Accessed: Apr. 26, 2019.

SHAH ALAM, S.; N. MOHAMED SAYUTI. Applying the Theory of Planned Behavior (TPB) in halal food purchasing. International journal of Commerce and Management, v.21, n.1, p.8-20. 2011. Available from: <https://doi.org/10.1108/10569211111111676>. Accessed: Dec. 26, 2018.

SMITH, S.; A. PALADINO. Eating clean and green? Investigating consumer motivations towards the purchase of organic food. Australasian Marketing Journal (AMJ), v.18, n.2, p.93-104. 2010. Available from: <https://doi.org/10.1016/j. ausmj.2010.01.001>. Accessed: Dec. 26, 2018.

SOMASUNDRAM, C., et al. A Review on organic food production in Malaysia. Horticulturae, v.2, n.3, p.12. 2016. Available from: $<$ https://doi.org/10.3390/horticulturae2030012>. Accessed: Sep. $26,2019$.

TARKIAINEN, A.; S. SUNDQVIST. Subjective norms, attitudes and intentions of Finnish consumers in buying organic food British Food Journal, v.107, n.11, p.808-822. 2005. Available from: <https://doi.org/10.1108/00070700510629760>. Accessed: Sep. 26, 2019.

TENG, C.-C.; C.-H. LU. Organic food consumption in Taiwan: Motives, involvement, and purchase intention under the moderating role of uncertainty. Appetite, v.105, p.95-105. 2016. Available from: https://doi.org/10.1016/j.appet.2016.05.006. Accessed: Sep. $26,2019$.

THOGERSEN, J. Consumer decision-making with regard to organic food products. Traditional food production and rural sustainable development: A European challenge, v.1, p.173192. 2009. Available from: <https://books.google.es/books?hl= en $\& 1 \mathrm{r}=\& \mathrm{id}=$ nxAuyQ1yArUC $\& \mathrm{o} i=$ fnd $\& \mathrm{pg}=\mathrm{PA} 173 \& \mathrm{dq}=\mathrm{THO}$ GERSEN,+J.+Consumer+decision-making + with + regard + to + organic + food + products. + Traditional + food + production + and $+r$ ural+sustainable+development:+A+European + challenge, + v. 1 , + p.173-192.+2009.+Dispon\%C3\%ADvel+em:+em.+doi.\&ots= LE6bqm_V3h\&sig=-mPthgR0tdSM6rpLYshK5EYrbIs\&redir $\mathrm{esc}=\mathrm{y} \# \mathrm{v}=$ onepage \&q\&f=false $>$. Accessed: Sep. 26, 2019.

WANG, X., et al. Factors Influencing Organic Food Purchase Intention in Tanzania and Kenya and the Moderating Role of Knowledge. Sustainability, v.11, n.1, p.209. 2019. Available from: $<$ https://doi.org/10.3390/su11010209>. Accessed: Sep. 26, 2019.

WILLER, H., et al. Organic farming and market development in Europe and the European Union. In: (Ed.): Research Institute of Organic Agriculture FiBL and IFOAM-Organics International, 2019. Organic farming and market development in Europe and the European Union, p.217-254

WILLER, H. L., J. The World of Organic Agriculture. Statistics and Emerging Trends 2019.Research Institute of Organic Agriculture FiBL and IFOAM Organics International. 2019. Available from: <https://www.organic-world.net/yearbook/ yearbook-2019.html>. Accessed: Jul. 26, 2019.

XIE, B., et al. Consumer perceptions and attitudes of organic food products in Eastern China. British Food Journal, v.117, n.3, p.1105-1121. 2015. Available from: $<$ https://doi.org/10.1108/BFJ09-2013-0255>. Accessed: Jul. 26, 2019.

Ciência Rural, v.50, n.5, 2020. 
YADAV, R.; G. S. PATHAK. Intention to purchase organic food among young consumers: Evidences from a developing nation. Appetite, v.96, p.122-128. 2016. Available from: <https://doi. org/10.1016/j.appet.2015.09.017>. Accessed: Jul. 16, 2019.

YAZDANPANAH, M.; M. FOROUZANI. Application of the Theory of Planned Behaviour to predict Iranian students' intention to purchase organic food. Journal of Cleaner Production, v.107, p.342-352. 2015. Available from: <https://doi.org/10.1016/j. jclepro.2015.02.071>. Accessed: Oct. 26, 2019.
ZAGATA, L. Consumers' beliefs and behavioural intentions towards organic food. Evidence from the Czech Republic. Appetite, v.59, n.1, p.81-89. 2012. Available from: <https:// doi.org/10.1016/j.appet.2012.03.023>. Accessed: Oct. 26, 2019.

ZION. Zion Market Research. Global organic trade guide: Report examines organic food and beverage growth. 2018. Available from: <https://globalorganictrade.com/reports $>$. Accessed: Oct. 26, 2019. 


\section{Erratum}

In the article "Methane Consumer preferences toward organic food and the moderating role of knowledge: a case of Pakistan and Malaysia" published in Ciência Rural, volume 50, number 5, DOI http://doi.org/10.1590/0103-8478cr20190842.

\section{In the author's afilliation, where we read:}

College of Economics and Management, Northeast Forestry University, Harbin, 150040, Heilongjiang, China. E-mail: umairkashif525@yahoo.com.*Corresponding author.

\section{Read:}

College of Economics and Management, Northeast Forestry University, Harbin, 150040, Heilongjiang, China. E-mail: nefuchenhong@ yeah.net. *Corresponding author.

\section{In the page 3, where we read:}

Moreover, information on sales figure 1 and perceptions about organic food in developing nations is still lacking (BANATI, 2011).

\section{Read:}

Moreover, information on sales figure and perceptions about organic food in developing nations is still lacking (BANATI, 2011). 